\title{
TEACHERS' PERCEPTIONS TOWARDS THE PRACTICE OF COMPETENCY BASED ASSESSMENT FOR LEARNING IN OROMIA COLLEGES: IN PARTICULAR TO SHAMBU, NAKAMTE AND D/DOLLO CTE
}

\author{
Moti Alemayehu \\ M.A. \\ Department of English Language, Shambu College of Teachers' Education, Wollega Oromia, Ethiopia \\ Tamiru Olana \\ Asst. Prof \\ Department of English Language and literature, Wollega University \\ P. O. Box: 395, Wollega Ethiopia \\ Ebisa Bekele \\ $(\mathrm{PhD})$ \\ Department of English Language and literature, Wollega University \\ P. O. Box: 395, Wollega Ethiopia
}

\begin{abstract}
This study investigated teachers' perceptions towards the practice of competency based assessment for learning in Shambu, Nakamte and D/Dollo College of Teachers Education in Oromia Region to realize their perceptions. Therefore, descriptive design was used. A close-ended and open-ended questionnaire items with five point Likert scale was administered to thirty two trainers. In addition, to substantiate the data obtained through questionnaires, interviews with 4 experienced instructors were also held. The quantitative data was analyzed to determine the status of instructors' perception towards the practice of CBAFL. The qualitative data which was collected using interview was described qualitatively using narrative analysis. Results of the study revealed that instructors' have unfavorable perception towards the practice of AFL. They perceived that the practice of CBAFL in the faculty was more of theoretical and most of them assumed that students need further practical training to perform to the standard in the actual job situations. Regarding the factors that affect the practice of assessment, almost all the participants believe the following are main factors: A heavy influence of the earlier approach to methods of
\end{abstract}

teaching and assessment (behaviorist) which is usually practiced by instructors; instructors give more attention to grading instead of enabling trainees to be competent through careful engagement of practical assessment tools; in addition the participants of the study also enlisted the following as main factors: trainees are not responsible for their own learning; they give priority to passing exams rather than developing competence; lack of clarity on competence-based assessment among trainee and instructors. Large numbers of respondents held the view that the practice of CBAFL was not in line with future job requirements of the graduates.

Key words: Competency- based curriculum, competency-based assessment, Constructivism, Perception, Assessment for learning

\section{INTRODUCTION}

Background of the Study

Competency-based education (CBE) emerged in the 1970 s in the US. It referred to an educational movement that advocated defining educational goals in terms of precise measurable description of the 


\section{International Journal of Engineering Applied Sciences and Technology, 2021 Vol. 6, Issue 3, ISSN No. 2455-2143, Pages 68-80 \\ Published Online July 2021 in IJEAST (http://www.ijeast.com)}

knowledge, skills, and behaviours students should possess at the end of a course of study (Guskey, 2005).

CBT is a teaching approach which focuses on the outcomes of learning. It emphasizes what learners are expected to achieve with the target objectives of the lesson. In other words, the approach sees outputs very importantly rather than the learning process. This means, starting with a clear picture of what is important for students to be able to do, then organizing curriculum, instruction, and assessment to make sure this learning ultimately happens.

The keys to having a competency-based system include developing a clear set of learning outcomes around which all of the system's components can be focused, and establishing the conditions and opportunities within the system that enable and encourage all trainees to achieve those essential outcomes. Recent studies mostly emphasized on researching how $\mathrm{CBE}$ relates to curriculum planning and assessment (Baartman et al, 2006). CBT is based on a functional perspective on teaching and its framework is often tailored to meet learners' needs and the skills they need can be fairly accurately predicted or determined. It also has a notion that the lesson form can be inferred from lesson function. That is, course designers should accurately predict the objectives that are possibly to be encountered in that particular situation and they can be organized into teaching and learning units. Learners are expected to meet standards framed around goals which are explicated by descriptors, sample progress indicators and classroom vignettes with discussions. Definitions of a series of short-term goals are clearly given and each builds upon the one before so that learners advance in knowledge and skill.

Docking (1994) summarized what CBT is: "it is designed not around the notion of subject knowledge but around the notion of competency. The focus moves from what trainees know about the lesson to what they can do with it. The focus on competencies or learning outcomes underpins the curriculum framework and syllabus specification, teaching strategies, assessment and reporting. Instead of normreferencing assessment, criterion-based assessment procedures are used in which learners are assessed according to how well they can perform on specific learning tasks (p.16)."

The positive consequence of implementing CBT is that it serves as an agent of change and it improves teaching and learning (Docking, 1994). Since competency-based approaches to teaching and assessment offer instructors an opportunity to revitalize their education and training programs, quality of assessment can be improved, and the quality of teaching and trainees learning will be enhanced by the clear specification of expected outcomes and the continuous feedback that competency-based assessment can offer.

The characteristics of $\mathrm{CBE}$ were described by Schneck (1978), "Competency-based education has much in common with such approaches to learning as performance-based and is adaptive to the changing needs of students, teachers and the community... (p.vi)" That is, what trainees learn depends on the needs of the stakeholders. However, who are the "stakeholders"? Whose needs are these? In this paper, the researcher intends to evaluate the perception of instructors towards implementing CBT. If learners are clear that the lesson is a potent element leading to career prospect and advancement, they have no objection to learning and improving competency. Through implementing competencybased approach, the researcher hopes to investigate teachers' perception towards CBA.

Assessment is the most important strategy we can do to help our students learn (Craddock, \& Mathias, 2009); Deibinger, et al. (2005). It is argued that, to be part of the learning process, assessment should be learner-centered and should reflect a learner-centered curriculum (Craddock, \& Mathias, 2009). The type of assessment used can also have a powerful influence on the learning behavior of students. In an earlier study, (Deibinger, et al. 2005). also stated that if tests do not measure important and meaningful content, skills, and knowledge, then precious time and resources are wasted. This implies that assessment instruments should be designed in such a way that they can measure the required competences of students which enables them to compete in the labor market. In doing so, offering a variety of assessment methods is often recommended as good practice. But, there should be a lesser concentration on traditional written assessments, particularly time constrained unseen exams, and a greater emphasis on assessment instruments that measure not just recall of facts, but the students' abilities to use the material they have learned in live situations competence and performance assessment. This conceptualization is further supported by previous studies (Allais, 2010).

It is known that in the contemporary world of work and context of globalization which is characterized by rapid and dramatic changes, the attainment of 


\section{International Journal of Engineering Applied Sciences and Technology, 2021 Vol. 6, Issue 3, ISSN No. 2455-2143, Pages 68-80 \\ Published Online July 2021 in IJEAST (http://www.ijeast.com)}

competence has become an integral component of individual, organizational and national strategies (Mahmood, 2004; Frere, 2010; Sadler, 1989).

Likewise, Brown (2004:82) explained that: "If we want our students to demonstrate employability when they graduate, our assessments need to be designed to be practice-orientated" means competence-based.

\section{Statement of the Problem}

The Ethiopian education and training policy (FDRE, 1994, 15) sub article 3.3.4 declared: "Higher education at diploma, first degree and graduate levels, will be research oriented, enabling students become problem-solver, professional leaders in their fields of study and in overall societal needs" Furthermore, Ethiopian Higher Education Proclamation No. 650/2009:4979 article 4 sub article 1 , that one of the objectives of higher education was to "prepare knowledgeable, skilled, and attitudinally mature graduates in numbers with demand-based proportional balance of fields and disciplines so that the country should become internationally competitive"

To achieve the above mentioned objectives, Higher Education Institutions (HEIs) in Ethiopia had embarked on major reforms since the last decade. For the reforms to took effect, the institutions had practiced Business Process Reengineering (BPR) as a tool. In the reengineering of the teaching-Learning Core Process, modularization was proposed as the best way for the implementation of curricula and the production of competent global graduates. There were a number of reasons why HEIs had chosen modularization; the existing curricula are discipline based and the courses are fragmented. They were not organized around competences. As a result, the curricula did not enable HEIs to produce competent

Hence, in 2012, the Ethiopian Higher Education Institutions started implementation of modularized curriculum with the intention of producing competent and well-equipped graduates. This was done all over the nation, in Oromo colleges too by taking competence-based education theory as a ground. Following this theoretical background, changes in the curriculum were made from fragmented courses to modular, where courses are organized in line with major competences. An alignment with earlier proclamations like Article 41 (Higher Education Proclamation No. 650/2009:5005-5006) which provides modes of students' assessment in HEIs was also made. Specifically, sub-article 41.4 offers details of assessment strategies including fairness in assessment and competency-based assessment for learning aligned with MLC (minimum learning competency of the lesson). All these details are similar to the constructive alignment theory of proponents like (Boud \& Falchikov 2006) who recommended to reform assessment in line with curriculum change.

However, it was observed that the assessment strategies in Oromo colleges especially Shambu, Nakamte and D/Dollo colleges as one of the HEIs of Oromo colleges are remain unchanged. The society at the work place of the graduates is complaining about the type of assessments given to them across colleges theoretically. They say that the competency of this day students is not which is aligned with the objective of the curriculum. Nevertheless, researchers like (Allais, 2010) argued that educational assessments should correspond to what is expected from students in the world of work. Accordingly, therefore, this study was aimed at exploring the perceptions of teachers' towards the practice of competency based assessment for learning in Oromo colleges. Though the problem is may be across the colleges of all oromo college, these colleges are selected since they have staffs with long-years of experiences to theories of learning, assessment and instruction. However, the researcher having the use of CBAFL and the goal of the country in mind, he is in doubt by himself about the competency of the trainer is aligned with objective of the lesson. The researcher himself is not believed about the competency of the graduates at their work place.

Therefore, the researcher feeling that the problem was not addressed well in relation to competency based assessment for learning. This had given him the desire to conduct a research to identify Teachers' Perceptions towards the Practice of Competency Based Assessment for Learning in Oromia Colleges: In Particular to Shambu, Nakamte and D/DolloCTE.

\section{Objectives of the Study}

\section{The specific objectives of the study are to:}

- assess the perception of instructors towards the practice of $\mathrm{CB}$ assessment for learning.

- identify the factors that affect the practice of CBAFL in the colleges.

\section{Research Questions}




\section{International Journal of Engineering Applied Sciences and Technology, 2021 Vol. 6, Issue 3, ISSN No. 2455-2143, Pages 68-80 \\ Published Online July 2021 in IJEAST (http://www.ijeast.com)}

- What perceptions do instructors have towards the practice of CBAF learning?

- What are the factors that affect the practice of CBAF learning?

\section{Significance of the Study}

The study had both theoretical and practical contributions. Theoretically, the findings would add some scientific concepts on the existing knowledge in general and in Ethiopian literature in particular. Practically, the information obtained from the research would help the colleges, instructors and other concerned bodies, with the quality of education, to work hard on the issues that improved the quality of graduates through improving the quality of education by giving special attention to competencebased learning and assessment.

\section{RESEARCH DESIGN AND METHODOLOGY}

\section{Research Design}

The study was a descriptive design and used both qualitative and quantitative approaches for data collection and analysis to seek out and describe the teachers' perceptions and preferences regarding CBA practices because it was difficult to fully explore the concept of CBA solely through one research method (Creswell, 2009).

The use of the qualitative approach enabled the researcher to develop an understanding of individuals and events in their natural settings, taking into account the relevant context. This study aimed at establishing teachers' perceptions towards CBA in the government colleges Oromia Zone. Therefore, the respondents would be asked to describe their everyday experiences relating to CBA (Creswell, 2009; Creswell, 2008; Creswell and Plano, 2011). Quantitative designs, on the other hand, were well suited for identifying general trends in populations (Creswell, 2009). This study used quantitative method to get some reviews on teachers' perspective on the current practices of CBA at their colleges and finally to draw a valid conclusion.

\section{Sources of Data}

In this study primary sources of data would be used. The primary sources of data would be teachers involved in the government colleges through interview and questionnaire.

\section{Sample Size and Sampling Technique}

\section{Population}

The target population for the study comprised all instructors of the Oromia colleges.

\section{Samples and sampling techniques}

The determination of the target population and sample colleges had been undertaken. As noted before; there are 12 government oromia colleges. Out of these, three colleges which represent $(25 \%)$ were selected using a purposive sampling technique. These colleges were Shambu, Nakamte, and D/Dollo, The rationale behind the use of a purposive sampling technique is that, the researcher noticed, after collecting a lot of information, that some colleges are not easily accessible in terms of transportation and/or for some other things. In Short, the proximity and the accessibility to the colleges had been taken as the main criteria for selecting those three colleges. The selected colleges were found to be representative because they had a combination of large, medium and small size range and characteristics of both urban and rural settings. The samples of the study who had purposively taken are 32 instructors.

\section{Data Collection Instruments}

In this research, data would be mainly collected through the use of questionnaire and interview methods, which were commonly employed in educational research, and typically inquire about the feelings, motivations, attitudes, accomplishments, and experiences of individuals (Creswell, 2009Literature study also provided theories on the research topic and clarifies some of the educational implications of the topic.

\section{Questionnaire}

As noted before in quantitative researches, data collection is normally done through the use of survey instruments. In this study, a survey questionnaire instrument was employed in collecting quantitative data. The survey instrument would be consisted of 31 questions administered to the samples to elicit their perceptions. Section one had focused on instructors' perceptions. In this section, respondents would be requested to indicate their perceptions of the actual (real) and ideal frequency of the use of the approaches.

The respondents were asked to respond to questions on a five-point Likert scale to indicate their level of 
agreement with each response. The opportunity for written responses was provided at the end of each section of the survey, requesting the respondents to share any other comments with the researcher. Comments would be used to enhance the presentation of data and to complement the discussion of the findings

\section{Interview}

In order to improve the trustworthiness of data, researchers suggest use of multiple data-collection methods or what is called "triangulation" process (Creswell, 2009). Triangulation process not only helps researchers to increase the credibility and validity of their study but also to eliminate biases that may result from relying exclusively on any one datacollection method, source, analyst or theory. To this end, this study employed interview as a second method to supplement or clarify issues raised in the questionnaire responses. Individual interviews were administered to a sample 4 of English teachers who were drawn from the survey questionnaire participants by using purposive sampling technique. Still, to ensure fair representation, 2 teachers are selected from two of the 3 selected colleges. According to Creswell, 2009), interview is qualitative approach and it mainly focuses on the participants' perspectives of the topic under study. In essence, it seeks the insight of the topic under study rather than generalization. For this, the sample size was usually small, purposefully selected based on the participants' knowledge of the topic (Creswell, 2009).

The qualitative data had been obtained through the use of semi-structured interviews that incorporated with open-ended questions to acquire specific answers to questions referring to teachers' perceptions of CBA practices. Because semistructured interview is flexible method (Creswell, 2009) and it doesn't only help the researcher to explore into areas on which participants are able to expand their ideas but also allowed the participants freedom to express their ideas about a variety of issues relating to teacher practice, not raised or limited in the survey.

\section{PROCEDURES OF DATA COLLECTION}

Subsequently, formal discussion on access to samples for collection of primary data would be sought. After getting permission, the researcher would develop interview schedules and questionnaire instruments, compiled, pilot tested and reviewed them. The researcher then would administer the questionnaire and conduct interviews with the respondents. Next, the data would be collected through the researcher himself. Then, data analyses would be carried out. Finally, writing of the project report would be undertaken and submitted to the college.

\section{METHODS OF DATA ANALYSIS}

The data collection techniques presuppose specific data analysis for qualitative and quantitative methods. Qualitative data analysis requires reading, describing, classifying and interpreting the collected data. Quantitative data analysis involves descriptive statistics. (Creswell, 2009) noted descriptive statistics as a mathematical technique for organizing, summarizing and displaying a set of numerical data.

In this research, the researcher would collect both quantitative and qualitative data from the respondents. The responses from each area covered would be coded to facilitate processing, checking and cross-referencing. Percentages would be applied to summarize items in the survey.

Data collected through open-ended questionnaire and interviews would be analyzed qualitatively. The researcher employed thematic and narrative qualitative techniques to analysis teachers' additional comments found at the end of the survey in order to identify notable themes or ideas (Creswell, 2009). The data were presented according to the research questions of the study. For each question, quantitative data are first described in the form of table, then, presentations of qualitative data are followed.

\section{RESULTS AND DISCUSSION}

Trainers' Perceptions of Competency- based Assessment for Learning thirty three questionnaire items with five point Likert scale were designed and presented to the trainers to identify their perception towards competency based assessment

Table 1 Identification of Competencies

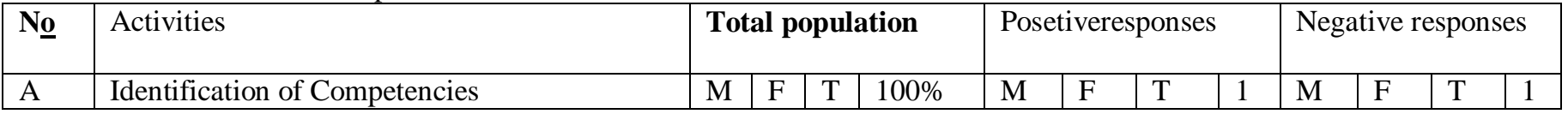


International Journal of Engineering Applied Sciences and Technology, 2021

Vol. 6, Issue 3, ISSN No. 2455-2143, Pages 68-80

Published Online July 2021 in IJEAST (http://www.ijeast.com)

\begin{tabular}{|c|c|c|c|c|c|c|c|c|c|c|c|c|c|}
\hline & & & & & & & & & $\begin{array}{l}0 \\
0 \\
\%\end{array}$ & & & & $\begin{array}{l}0 \\
0 \\
\%\end{array}$ \\
\hline 1 & $\begin{array}{l}\text { Competencies to be achieved by the trainees } \\
\text { are derived from occupational standards. }\end{array}$ & 30 & 2 & $\begin{array}{l}3 \\
2\end{array}$ & 100 & 28 & 2 & 30 & $\begin{array}{l}9 \\
3 . \\
7 \\
5\end{array}$ & 2 & - & 2 & $\begin{array}{l}6 . \\
2 \\
5\end{array}$ \\
\hline 2 & $\begin{array}{l}\text { Competencies to be achieved are specific, } \\
\text { precise and stated in a written form. }\end{array}$ & 30 & 2 & $\begin{array}{l}3 \\
2\end{array}$ & 100 & 30 & 1 & 31 & $\begin{array}{l}9 \\
6 . \\
8 \\
8\end{array}$ & - & 1 & 1 & $\begin{array}{l}3 . \\
1 \\
2\end{array}$ \\
\hline
\end{tabular}

As shown in table 1 above, in item No 1 competences to be achieved by trainees are derived from occupational standards 30(93.75\%) of the respondents were perceived positively, whereas the remaining $2(6.25 \%)$ were negatively perceived. This shows that the modules contain competencies (knowledge, skill, a bilities) to be demonstrated by the trainees that are derived from occupational standards.

However, competencies to be achieved by the trainees need to be publicized in advance for effective implementation of competency-based curriculum. This idea is consistent with NCTVET (2006), which has indicated that, in competencybased instruction, trainees are informed about the criteria and attitudes that are important to the occupation.

Therefore, if competencies to be achieved by the trainees are derived from occupational standards as the positive respondents said, the trainees are at their level of quality and competent enough in their occupation.

As the qualitative data indicated from interview 4 of the respondents perceived positively if competences to be achieved by trainees are derived from occupational standards Knowledge, skill and attitude of trainees are effectively achieved.

Furthermore, 31(96.88\%) of the respondents perceive positively indicates that, competencies to be achieved need to be specific, precise and stated in written form. Again, this idea corresponds with the work of Brown (1994), one of the characteristics of competency based instruction is that whatever students learn is based on specific, precisely stated outcomes that have been recently identified as being essential for successful employment in occupation for which the trainee is being trained. These competencies are made available to all concerned exactly with what the students will be able to do upon completion of their training.

Table 2 Teaching- learning (presentation)

\begin{tabular}{|c|c|c|c|c|c|c|c|c|c|c|c|c|c|}
\hline № & Activities & \multicolumn{4}{|c|}{ Total population } & \multicolumn{4}{|c|}{ Positive responses } & \multicolumn{4}{|c|}{ Negative responses } \\
\hline B & Teaching- learning (presentation) & $\mathrm{M}$ & $\mathrm{F}$ & $\mathrm{T}$ & $100 \%$ & $\bar{M}$ & $\mathrm{~F}$ & $\mathrm{~T}$ & $\begin{array}{l}1 \\
0 \\
0 \\
\%\end{array}$ & $\mathrm{M}$ & $\mathrm{F}$ & $\mathrm{T}$ & $\begin{array}{l}1 \\
0 \\
0 \\
\%\end{array}$ \\
\hline 1 & $\begin{array}{l}\text { The role of instructors are as facilitator of } \\
\text { learning }\end{array}$ & 30 & 2 & $\begin{array}{l}3 \\
2\end{array}$ & 100 & 28 & 2 & 30 & $\begin{array}{l}8 \\
7 . \\
5\end{array}$ & 2 & - & 2 & $\begin{array}{l}6 . \\
2 \\
5\end{array}$ \\
\hline 2 & $\begin{array}{l}\text { It is integrated with knowledge, skill and } \\
\text { attitude }\end{array}$ & 30 & 2 & $\begin{array}{l}3 \\
2\end{array}$ & 100 & 28 & 2 & 30 & $\begin{array}{l}9 \\
3 . \\
7 \\
5\end{array}$ & 2 & - & 2 & $\begin{array}{l}6 . \\
2 \\
5\end{array}$ \\
\hline 3 & $\begin{array}{l}\text { Teaching- learning activities are interactive } \\
\text { during CBA }\end{array}$ & 30 & 2 & $\begin{array}{l}3 \\
2\end{array}$ & 100 & 29 & 2 & 31 & $\begin{array}{l}9 \\
6 . \\
8 \\
8\end{array}$ & 1 & - & 1 & $\begin{array}{l}3 . \\
1 \\
2\end{array}$ \\
\hline
\end{tabular}




\section{International Journal of Engineering Applied Sciences and Technology, 2021 \\ Vol. 6, Issue 3, ISSN No. 2455-2143, Pages 68-80 \\ Published Online July 2021 in IJEAST (http://www.ijeast.com)}

\begin{tabular}{|c|c|c|c|c|c|c|c|c|c|c|c|c|c|}
\hline 4 & Makes trainees learn at their own pace. & 30 & 2 & $\begin{array}{l}3 \\
2\end{array}$ & 100 & 26 & 2 & 28 & $\begin{array}{l}8 \\
7 . \\
5\end{array}$ & 4 & - & 4 & $\begin{array}{l}- \\
1 \\
2 . \\
5\end{array}$ \\
\hline 5 & $\begin{array}{l}\text { Make trainees demonstrate their competencies } \\
\text { during learning }\end{array}$ & 30 & 2 & $\begin{array}{l}3 \\
2\end{array}$ & 100 & 28 & 2 & 30 & $\begin{array}{l}9 \\
3 . \\
7 \\
5\end{array}$ & 2 & - & 2 & $\begin{array}{l}6 . \\
2 \\
5\end{array}$ \\
\hline 6 & Learning is modular based & 30 & 2 & $\begin{array}{l}3 \\
2\end{array}$ & 100 & 30 & 2 & 32 & $\begin{array}{l}1 \\
0 \\
0\end{array}$ & - & - & - & - \\
\hline 7 & $\begin{array}{l}\text { Enables as learning is field centered using } \\
\text { realistic work situation. }\end{array}$ & 30 & 2 & $\begin{array}{l}3 \\
2\end{array}$ & 100 & 30 & 2 & 32 & $\begin{array}{l}1 \\
0 \\
0\end{array}$ & - & - & - & - \\
\hline 8 & $\begin{array}{l}\text { Make instruction of each task package is } \\
\text { supported by practice. }\end{array}$ & 30 & 2 & $\begin{array}{l}3 \\
2\end{array}$ & 100 & 30 & 2 & 32 & $\begin{array}{l}1 \\
0 \\
0\end{array}$ & - & - & - & - \\
\hline 9 & $\begin{array}{l}\text { Immediate feedback is provided by the trainers } \\
\text { on performance after each practice. }\end{array}$ & 30 & 2 & $\begin{array}{l}3 \\
2\end{array}$ & 100 & 30 & 2 & 32 & $\begin{array}{l}1 \\
0 \\
0\end{array}$ & - & - & - & - \\
\hline 10 & $\begin{array}{l}\text { Incorrect practices in instruction for each task } \\
\text { package is } \\
\text { detected and corrected }\end{array}$ & 30 & 2 & $\begin{array}{l}3 \\
2\end{array}$ & 100 & 30 & 2 & 32 & $\begin{array}{l}1 \\
0 \\
0\end{array}$ & & & & \\
\hline 11 & $\begin{array}{l}\text { Trainees are allowed to practice tasks correctly } \\
\text { before being evaluated. }\end{array}$ & 30 & 2 & $\begin{array}{l}3 \\
2\end{array}$ & 100 & 30 & 2 & 32 & $\begin{array}{l}1 \\
0 \\
0\end{array}$ & - & - & - & - \\
\hline 12 & $\begin{array}{l}\text { Learning activity is reinforced until } \\
\text { competency is } \\
\text { Achieved }\end{array}$ & 30 & 2 & $\begin{array}{l}3 \\
2\end{array}$ & 100 & 30 & 2 & 32 & $\begin{array}{l}1 \\
0 \\
0\end{array}$ & - & - & - & - \\
\hline & & & & & & & & & & & & & \\
\hline
\end{tabular}

As shown in the table 2 above, item No 1 about the role of instructors are as facilitator of learning $30(93.75 \%)$ of the respondents perceive positively, but $2(6.25 \%)$ of the respondents are negatively perceived. According to Piagetian theory, humans cannot be 'given' information which they immediately understand and use; they must 'construct' their own knowledge through experience. To this end, they need to have interactions with other people and social factors. In the Vedic teaching method, teachers deliver lectures on a topic standing at the front where students are considered as passive listeners. But as the time passed, people developed different concepts regarding teaching learning theories. Now it is believed, "there is no lesson which can be done without an interaction in the classroom." An old Chinese proverb resonate the importance of interaction: if you listen you forget; if you see, you remember; and if you do, you learn. Hence the modern academic world has introduced constructivism - inquiry based learning which believes in the learner-centeredness in education.
With the assumption, students or learners have become a prime focus of all the teaching learning activities in the classroom.

The qualitative data also revealed the same positive response as given for the questionnaires. The response from the interview from 4 trainers indicate the same response as that of the questionnaire that during competency based assessment trainees are active participants and they play the role of active participant in the teaching learning process and trainers conduct classes based on experiment and practice using simulation, role-play, dramatization, strip story, group work, pair work, elicitation and project work, instead of simply giving speeches (Subedi, 2005). Therefore, teachers are more popularly known as facilitators, managers, and inspirers rather than a mere classroom teacher.

Therefore, it is true that if teaching is meant for imparting knowledge or skill to learners through instruction or to provide content of a subject, learning or to learn is meant for acquiring knowledge. In this sense, instructors and facilitators have 


\section{International Journal of Engineering Applied Sciences and Technology, 2021 Vol. 6, Issue 3, ISSN No. 2455-2143, Pages 68-80 \\ Published Online July 2021 in IJEAST (http://www.ijeast.com)}

different concepts. Instructors' impart knowledge or skill through instruction while facilitators create an environment where students acquire knowledge by doing activities themselves.

As given in the table above, in item NO 2 about the integrity of knowledge, skill and attitude 30(93.75\%) of the respondents perceived positively and $2(6.25 \%)$ of the respondents perceived negatively. This implies that if competency based assessment is integrated with knowledge, skill and attitude in teaching learning activities, it was believed that the trainee's are competent enough. Similarly, this reveals that if knowledge, skill and attitude are integrated during training the less likely the trainees to be incompetent in assessment. Therefore, it is important to integrate knowledge, skill and attitude during competency based training and assessment to enhance the competence of trainees.

As the qualitative data showed similar response that they believed if a trainee is competent he/she should develop the skill, knowledge and attitude and performs an expected standard. This indicates that the integration of skills, knowledge and attitudes enables one to effectively perform the activities of a given expected standards and competent person so that a trainee who can apply all domains (knowledge, skill and attitude) and perform something in a real world context.

Concerning the teaching- learning activities are interactive during CBA 31(96.88\%) of the respondents perceived positively, but $1(3.12 \%)$ of the respondents perceived negatively. This shows that interactive Teaching and Learning Activities (also called "Student Engagement Techniques") can provide opportunities for trainees to engage with content in the classroom. These techniques can provide instructors with immediate feedback about trainees' learning, helping identify student misconceptions, confusions, etc. They can also be used as practice exercises that help prepare trainees for formal assessments such as homework assignments, exams, etc.

One of the respondents of the interviewee said:

"Trainees learn through their participation in the attainment of knowledge by gathering information and processing it by solving problems and articulating what they have discovered. "

For item NO 4 above, the teaching learning process in competency based learning makes the trainees learn at their pace is perceived by $28(87.5 \%)$ of the respondents, but $4(12.5 \%)$ of the respondents perceive negatively. This shows that implementation of competency based curriculum, is one of the basic characteristics that trainees are trained at their own pace. The idea of self paced instruction was supported by the work of Watson (1991), who stated that competency based instruction is characterized by self-paced learning. Self-paced instruction is characterized by allowance being made for trainees to move through a course at different rates. This implies that competency-based instruction normally allows students to acquire the specific competencies more or less at their own pace of learning through variety of self-paced learning strategies and materials and frequent feedback. Self-paced learning is more flexible and self-satisfying.

It develops habits of self-reliance and independence, thereby helping the trainees in gaining and holding employment, which is the core principle of competency based instruction. It allows open entry and open exit practices to be followed by institutions so that trainees will have the opportunity to quit and return based on their need. This idea complements the view of Nizam's et el. (2009), which states that the self-paced nature of the approach allows opportunities for higher ability trainees to undertake extension work.

From the table 2 above, item No 5 30(9193.75\%) of them perceived positively, but $2(6.25 \%)$ of the respondents perceived negatively, which refers to a wide variety of potential educational projects, presentations, or products through which students "demonstrate" what they have learned, usually as a way of determining whether and to what degree they have achieved expected learning standards or learning objectives for a course or learning experience. This reveals that demonstration of learning is typically both a learning experience in itself and a means of evaluating academic progress and achievement. Assessment that is based on actual demonstration of competencies during training also contributes to the achievement of competence of trainees. This implies that, the more training is based on actual demonstration of competencies, the less likely the trainees to be incompetent in assessment. Therefore, training should be based on actual demonstration of competencies to strengthen trainees' competence.

As shown in table 2, item NO 6 above 32(100\%) of the respondents perceived positively, which shows if the learning is modular based it is advantageous in competency based assessment for learning (Kogan- 


\section{International Journal of Engineering Applied Sciences and Technology, 2021 \\ Vol. 6, Issue 3, ISSN No. 2455-2143, Pages 68-80 \\ Published Online July 2021 in IJEAST (http://www.ijeast.com)}

Page, 1999) describing some of the advantages of using a modular structure. There are several advantages to a modular presentation. The most important one is that it allows for better evaluation and more focused revision and improvement. Modifying a module is easier and more cost effective than revising a course or one large module. Another advantage to a modular approach is that parts of the course can be used and reused elsewhere in other courses. Courses that are already in a modular format are ultimately more flexible and easier to convert for delivery in other formats. Furthermore, if training is modular based, the assessments aligned with the objectives of the module so that the trainees achieve their competency.
As indicated in the table above, most of the respondents perceive that in competency based instruction, if attention is given to incorrect practices which need to be corrected immediately during presentation of the subject matter or during conducting practices competency may be achieved. Similarly, 'learning activity is reinforced until competency is achieved. This implies that each trainee should be provided with reasonable and enough time to fully master one task before being allowed to move to the next and immediate feedback should be provided during each task. This perspective coincides with the view of Brown (1994), who stated that the integral part of competency based instruction is periodic feedback throughout the learning process with opportunities for trainees to correct their performance as they do.

Table 3 The CBAf Learning Material

\begin{tabular}{|c|c|c|c|c|c|c|c|c|c|c|c|c|c|}
\hline $\mathrm{C}$ & The CBAf Learning Material & $\mathrm{M}$ & $\mathrm{F}$ & $\mathrm{T}$ & $100 \%$ & $\mathrm{M}$ & $\mathrm{F}$ & $\mathrm{T}$ & $\begin{array}{l}1 \\
0 \\
0 \\
\%\end{array}$ & $\mathrm{M}$ & $\mathrm{F}$ & $\mathrm{T}$ & $\begin{array}{l}1 \\
0 \\
0 \\
\% \\
\end{array}$ \\
\hline 1 & Learning materials should be well organized. & 30 & 2 & $\begin{array}{l}3 \\
2\end{array}$ & 100 & 30 & 2 & 32 & $\begin{array}{l}1 \\
0 \\
0\end{array}$ & - & - & - & \\
\hline 2 & $\begin{array}{l}\text { Learning materials for instruction should be } \\
\text { appropriate for the } \\
\text { Tasks }\end{array}$ & 30 & 2 & $\begin{array}{l}3 \\
2\end{array}$ & 100 & 30 & 2 & 32 & $\begin{array}{l}1 \\
0 \\
0\end{array}$ & - & - & - & \\
\hline 3 & $\begin{array}{l}\text { Learning materials should be available for } \\
\text { every task }\end{array}$ & 30 & 2 & $\begin{array}{l}3 \\
2\end{array}$ & 100 & 30 & 2 & 32 & $\begin{array}{l}1 \\
0 \\
0\end{array}$ & - & - & - & \\
\hline 4 & $\begin{array}{l}\text { Learning equipments are relevant to the } \\
\text { occupation in the world of work }\end{array}$ & 30 & 2 & $\begin{array}{l}3 \\
2\end{array}$ & 100 & 30 & 2 & 32 & $\begin{array}{l}1 \\
0 \\
0\end{array}$ & - & - & - & \\
\hline 5 & $\begin{array}{l}\text { Learning materialsshould be effectively } \\
\text { utilized during } \\
\text { instruction. }\end{array}$ & 30 & 2 & $\begin{array}{l}3 \\
2\end{array}$ & 100 & 30 & 2 & 32 & $\begin{array}{l}1 \\
0 \\
0\end{array}$ & - & - & - & \\
\hline 6 & Learning materials should be comprehensive. & 30 & 2 & $\begin{array}{l}3 \\
2\end{array}$ & 100 & 30 & 2 & 32 & $\begin{array}{l}1 \\
0 \\
0\end{array}$ & - & - & - & \\
\hline
\end{tabular}

As it is indicated in the above table most of the respondents, perceive positively revealing that if the learning materials and supplementary materials are aligned with contents of the lesson and objective of the courses competency based learning can be achieved. Therefore, in implementing competency based curriculum in program, one of the basic tasks is the organization of learning resources. The principle of organizing learning resources in implementing competency based curriculum is supported by Brown
(1994), who stated that one of the characteristics of competency based instruction program is the effective utilization of resources. The reason behind organizing learning materials is to help all trainees to be efficient and develop marketable skills. Likewise, if materials and equipment are not relevant to the occupation in the world of work and, as a result, learning materials are not effectively utilized during instruction.

Thus, since competency based instruction requires practical exercises and hands on practice during 


\section{International Journal of Engineering Applied Sciences and Technology, 2021 \\ Vol. 6, Issue 3, ISSN No. 2455-2143, Pages 68-80 \\ Published Online July 2021 in IJEAST (http://www.ijeast.com)}

training, the shortage, inappropriateness and non relevance of the instructional resources to the occupation in the world of work appears to have highly affected the competency of trainees.

Table 4 Assessment

\begin{tabular}{|c|c|c|c|c|c|c|c|c|c|c|c|c|c|}
\hline No & Activities & To & al $p$ & pu & ation & Pos & ve & pon & & & ive & spo & \\
\hline $\mathrm{D}$ & Assessment & $\mathrm{M}$ & $\mathrm{F}$ & $\mathrm{T}$ & $100 \%$ & $\mathrm{M}$ & $\mathrm{F}$ & $\mathrm{T}$ & $\begin{array}{l}1 \\
0 \\
0 \\
\%\end{array}$ & $\mathrm{M}$ & $\mathrm{F}$ & $\mathrm{T}$ & $\begin{array}{l}1 \\
0 \\
0 \\
\%\end{array}$ \\
\hline 1 & $\begin{array}{l}\text { Assessment should engage students in applying } \\
\text { knowledge in the } \\
\text { same way as they are used in the real world } \\
\text { outside of } \\
\text { school. }\end{array}$ & 30 & 2 & $\begin{array}{l}3 \\
2\end{array}$ & 100 & 30 & 2 & 32 & $\begin{array}{l}1 \\
0 \\
0\end{array}$ & - & - & - & - \\
\hline 2 & $\begin{array}{l}\text { Assessment should engage students in applying } \\
\text { skills in the same } \\
\text { way as they are used in the real world outside } \\
\text { of school. }\end{array}$ & 30 & 2 & $\begin{array}{l}3 \\
2\end{array}$ & 100 & 30 & 2 & 32 & $\begin{array}{l}1 \\
0 \\
0\end{array}$ & - & - & - & - \\
\hline 3 & Assessment should be continuous & 30 & 2 & $\begin{array}{l}3 \\
2\end{array}$ & 100 & 30 & 2 & 32 & $\begin{array}{l}1 \\
0 \\
0\end{array}$ & - & - & - & - \\
\hline 4 & $\begin{array}{l}\text { Assessment should be based on actual } \\
\text { demonstration of } \\
\text { competency. }\end{array}$ & 30 & 2 & $\begin{array}{l}3 \\
2\end{array}$ & 100 & 30 & 2 & 32 & $\begin{array}{l}1 \\
0 \\
0\end{array}$ & - & - & - & - \\
\hline 5 & $\begin{array}{l}\text { Students should be aware that assessment is } \\
\text { based on occupational standards. }\end{array}$ & 30 & 2 & $\begin{array}{l}3 \\
2\end{array}$ & 100 & 30 & 2 & 32 & $\begin{array}{l}1 \\
0\end{array}$ & - & - & - & - \\
\hline 6 & $\begin{array}{l}\text { Trainees should aware of how and when } \\
\text { competencies will be } \\
\text { evaluated. }\end{array}$ & 30 & 2 & $\begin{array}{l}3 \\
2\end{array}$ & 100 & 30 & 2 & 32 & $\begin{array}{l}1 \\
0 \\
0\end{array}$ & - & - & - & - \\
\hline 7 & $\begin{array}{l}\text { Assessment should enable trainees to show } \\
\text { what they know by using actual tools that } \\
\text { reflect actual work area. }\end{array}$ & 30 & 2 & $\begin{array}{l}3 \\
2\end{array}$ & 100 & 30 & 2 & 32 & $\begin{array}{l}1 \\
0 \\
0\end{array}$ & - & - & - & - \\
\hline 8 & $\begin{array}{l}\text { Trainees should be assessed } \\
\text { predetermined standards }\end{array}$ & 30 & 2 & $\begin{array}{l}3 \\
2\end{array}$ & 100 & 30 & 2 & 32 & $\begin{array}{l}1 \\
0 \\
0\end{array}$ & - & - & - & - \\
\hline
\end{tabular}

As shown in table 4 above in item NO 1 , all of the respondents answer positively. This indicates that if trainees are engaged in competency based assessment in their knowledge, similarly they use it in the real world of work outside of school. According to the principle of competency based training, however, trainees should practice the knowledge that they need in the real world of work.

Engaging trainees during assessment in applying skills in the same way as the real world outside 


\section{International Journal of Engineering Applied Sciences and Technology, 2021 \\ Vol. 6, Issue 3, ISSN No. 2455-2143, Pages 68-80 \\ Published Online July 2021 in IJEAST (http://www.ijeast.com)}

school also contributes to competence of trainees in assessment. All of the respondents perceived positively. This reveals that, assessment engages trainees in applying skills in the same way as the real world of work.

According to capper (1996), the following purpose of assessment were suggested improving instructional materials, regarding how effective teaching procedures, activities, the text book, and other materials are in teaching, improving trainees learning. Both instructors and trainees need to know how tyey are doing. First, of course, they should know that the goal is towards which the learners are studying what they eventually need to know or to be able to do. If through assessment instructors and trainees get feedback as to what they already know have learned or do not know get, then instructors can direct students study appropriately to learn the remaining material, teaching assessment activities, if appropriately planned and used, can be powerful learning activities. On the other hand, Plessis et al, (2003:9) has identified reasons for using CA as: To improve teaching, to lead the overall evaluation, to find out what trainees know and can do, to promote learning for understanding, to let parents know how their children are progressing, to gain confidence in what we say our trainees know and to provide all children with opportunities to show what they know, to let trainees know how well they are in their our learning, to determine what kind of remediation and enrichment activities to provide, and to identify which of them need help. In general the purpose of assessment circles around improving teachinglearning activity, addressing trainees' interest in the course of learning and creates an opportunity for both instructors and instructors to work for the same purpose-improving trainees ${ }^{\text {ee }}$ learning. So, in order to make assessment activity fruitful, prior to the implementation teachers are expected to suit their assessment activity to serve the above listed purpose. One of the most important reasons for conducting assessment continuously is to inform trainers about their trainees progress areas where they are lagging. When trainers understand how their trainees are performing, they have the information they need to adjust their teaching and recommended supplementary materials for remediation and enrichment.

Occupational standards define the competencies of a worker according to the requirements in the labour market. Furthermore, occupational standards comprehensively describe the competence a person has to achieve in order to be considered qualified in a certain field. Competence includes the entire range of skills, knowledge and attitude necessary to perform a specific job (MOE, 2008).

Occupational standards are used to describe a job role or occupation. It specifies the standards of performance that the trainees are expected to achieve in their work, and knowledge and skills they need to perform effectively. An occupational standard is seen as a benchmark against which the actual performance of individuals can be compared and assessed as competent or not (Mahmood, 2004). It is like the study statement in a position or job description. These statements describe what a person in particular job is required to achieve and specify the standard to which the job should be done (Brown, 1994).

Standards have a great contribution to human lives. Without standards it is impossible to compare, judge and use many of the products and services over the world. Occupational standards describe the skills, knowledge and attitude needed to perform competently in the work place (Mahmood, 2004).

As indicated in table 4 above in item No 6 $20(83.3 \%)$ of the respondents perceived positively, but $4(17 \%)$ of the respondents perceive negatively. This reveals that trainees should be aware of when and how competencies will be assessed. This idea is consistent with the view of DenBinger (2005), who stated that assessment procedures should be made accessible to trainees so that they can proceed readily from one competence standard to the other.

Also, trainees should be assessed against certain predetermined standards so that they can prepare themselves for the real world of work. Though trainees should be provided with the above mentioned training assessment principles, the respondents replied that if these activities were not well practiced during their assessments, consequently this would have an impact on the success of trainees during assessment.

Table 5 Record Keeping

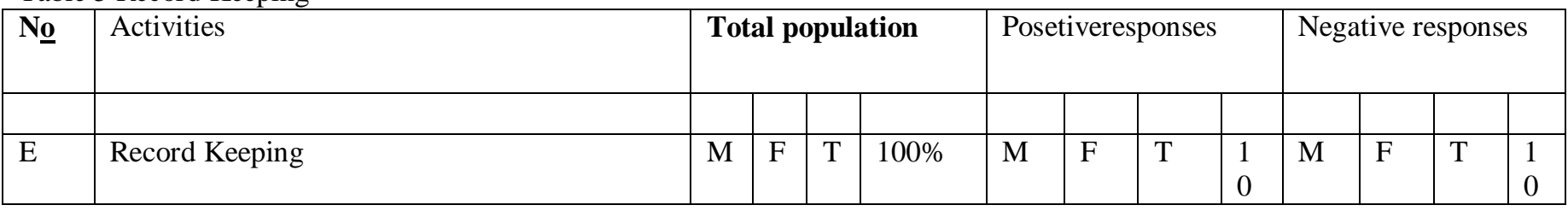


International Journal of Engineering Applied Sciences and Technology, 2021

Vol. 6, Issue 3, ISSN No. 2455-2143, Pages 68-80

Published Online July 2021 in IJEAST (http://www.ijeast.com)

\begin{tabular}{|c|c|c|c|c|c|c|c|c|c|c|c|c|}
\hline & & & & & & & & & $\begin{array}{l}0 \\
\% \\
\end{array}$ & & & $\begin{array}{l}0 \\
\% \\
\end{array}$ \\
\hline 1 & $\begin{array}{l}\text { There should be a record of trainee's } \\
\text { competency during } \\
\text { instructional process }\end{array}$ & 30 & 2 & $\begin{array}{l}3 \\
2\end{array}$ & 100 & 30 & 2 & 32 & $\begin{array}{l}1 \\
0 \\
0\end{array}$ & - & - & - \\
\hline 2 & $\begin{array}{l}\text { Score of students must be continuously } \\
\text { recorded. }\end{array}$ & 30 & 2 & $\begin{array}{l}3 \\
2\end{array}$ & 100 & 30 & 2 & 32 & $\begin{array}{l}1 \\
0 \\
0\end{array}$ & - & - & - \\
\hline 3 & $\begin{array}{l}\text { Progress record chart should be used during } \\
\text { learning process }\end{array}$ & 30 & 2 & \begin{tabular}{|l|}
3 \\
2
\end{tabular} & 100 & 30 & 2 & 32 & $\begin{array}{l}1 \\
0 \\
0\end{array}$ & - & - & - \\
\hline
\end{tabular}

As indicated in the tables 5 above all of respondents perceive positively this shows that maintaining an accurate set of records for competency based instruction system is necessary for program effectiveness. The score of trainees plus a wide variety of other information should be recorded continuously in order to make the competency record a useful set of data for the instructor. There are several specific reasons why the instructor must have an efficient record keeping system. One of the most important reasons is that, an effective method of tracing an individual trainees' progress can reduce the instructor's heavy management load. A good set of competency records allow the instructor to assess the relative performance of each trainees at a glance. Appropriate learning activities can be selected on which the trainees can work as a result of competency recording (Perry and William, 1994).

According to Perry and William, effective record keeping in competency based training helps to report trainees' progress accurately, assess their performance instantly, provide a detailed transcript for use by employers and supply documented evidence for program accountability. Also, it serves as a basis for evaluating program effectiveness and it is a base for evaluating trainee performance.

Trainers use various methods of keeping track of trainee's' progress on assessments. The assessments need not to be graded, but they may be marked it in different ways so that the trainer can follow trainee's progress over time. In continuous assessment, the recording of marks is timely, consistent and low maintenance so that instructors have an accurate picture of their trainee's performance of at all times. Recording results from observation or rubric development and recording accordingly and etc.

Finally, using progress record chart during training contributes to the competence of trainees in assessment. This indicates that the more progress record chart is used during training, the less likely will the trainees be incompetent.
Assessment is designed so that trainees understand their progress towards course goals and modify their behavior in order to meet those goals. In order to do that, CBAFL should be on going. In other words, classes that use one or two exams a term are not using assessment as effectively as it could be used. In order for trainees to gain a true representation of their understanding, frequent assessment is critical, and it should be accompanied with feedback. Assessment is really only as good as the feedback that accompanies it. Feedback is the instructors' response to trainees' work. In order to make assessment as effective as possible, instructors should provide their feedback. It is important that trainees understand why a particular question was incorrect.

\section{CHALLENGES DURING THE IMPLEMENTATIONS OF CBAFL}

The major challenges are large class size, lack of understanding of CBA, staffing teaching and learning resource and instructors' networking are major challenges in implementing $\mathrm{CB}$ assessment. In addition, Sarwar (2011) cited in Muluken,A.(2006). Also identified the problems that teachers raised in relation to large class size. This include: Teachers feel self conscious, nervous and uncomfortable under eyes of many students, problems in evaluating oral and written work, shortage of time to help individual students, discipline and classroom problems.

\section{CONCLUSION}

As it is already indicated by researchers in the field of competency theory, competence based curricula should be contextualized practice (authentic environment), multiple assessors, integration of instruction and assessment, collaborative culture, increased trainees responsibility for learning, transparency of assessment, provision of appropriate 


\section{International Journal of Engineering Applied Sciences and Technology, 2021 Vol. 6, Issue 3, ISSN No. 2455-2143, Pages 68-80 \\ Published Online July 2021 in IJEAST (http://www.ijeast.com)}

and timely feedback to trainees, and changing role of instructors from lecturers to facilitators, among many others. Unfortunately, these CBA principles were found not properly practiced. Though the government of Federal Democratic Republic of Ethiopia declared; particularly, in its proclamations that HEIs should follow competence-based approach and introduced business process reengineering to foster the reform, instructors were still practicing the behaviorist paradigm. This paradigm, in its turn, is accused of fragmentation of learning. Therefore, competencebased education and competence-based assessment though formalized in legal documents; it is concluded, are still practiced as the resemblance of behaviorist approach.

\section{REFERENCES}

Allais S. (2010). The implementation and impact of National Qualification Framework: report of a study in 16 countries. Geneva: International Labour Office.

Baartman, L., Bastiaens, T., Kirschner, P., and van der Vleuten, C. (2007). Evaluating assessment quality in competence-based education: A qualitative comparison of two frameworks. Educational Research Review,2(2), 114-129.

Boud, D., and Falchikov, N. (2006). Aligning assessment with long-term learning. Assessment \& Evaluation in Higher Education, 31(4), 399-413.

Brown, S. (2004). Assessment for learning. Learning and teaching in higher education, 1(1), 81-89.

Brown, M. (1994). A Collection of Readings Related to Competency Based Training. Victoria: Deakam University.

Craddock, D., and Mathias, H. (2009). Assessment options in higher education. Assessment \& Evaluation in Higher Education, 34(2), 127140.

Creswell, w. (2009). Research design: Qualitative, quantitative, and Mixed approach. Third Edition. London: Sage.

Deibinger, et al. (2005). Structures and Functions of Competence-based Education and

Training (CEBT): A Comparative Perspective. Mannhiem: InWent.

FDRE(2009). Higher Education Proclamation: Proclamation No. 650/2009. Federal Negarit Gazeta, pp. 4976- 5044.
FDRE. (1994.) Education and Training Policy. Addis Ababa: St. George Printing Press.

MOE. (2008). Ethiopian Occupational Standards Development Guideline. Addis Ababa:

Mahmood, T. (2004). Occupational standards quality assurance and accreditation performance criteria. Retrieved on 1/4/2012 from htt:www.apacc4hrd.org/conf workshop/apacc04/TP/05.

NCTVET, (2006). A coordinators guide to implementing competency based education.

Jamaica: NCTVET. (2006). Assessment in competency based education. Jamaica: NCTVET

Sadler, D. (1989), Formative assessment and the design of instructional systems. Instructional science, 18(2), 119-144.

Frere, C. (2010). Developing a Competency Based Curriculum. Virginia: west Verginia University. New Jersey: Pearson. 